\title{
ATP Hydrolysis Analysis of Severe Acute Respiratory Syndrome (SARS) Coronavirus Helicase
}

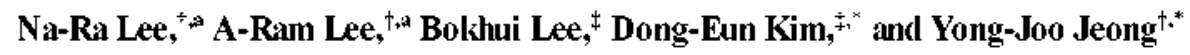 \\ ${ }^{\dagger}$ Department of Bio and Nanochemistry, Kookmin Unversity, Seoul 136-702, Korea. ${ }^{*}$ E-mail jeongyakookmin ac.kr \\ ${ }^{\ddagger}$ Department of Bioscience and Biotechologv. Konkuk Universin. Seoul 143-701, Korea. E-mail: kimde akonkuk.ackr \\ Received May 15, 2009, Accepted June 11, 2009
}

\begin{abstract}
Severe acute respiratory syndrome coronavirus (SARS-CoV) helicase separates the double-stranded nucleic acids using the energy from ATP hydroly sis. We have measured ATPase activity of SARS-CoV helicase in the presence of various types of nucleic acids. Steady state ATPase analysis showed that poly(U) has two-times higher tumover number than poly (C) with lower Michaelis constant. When Ml3 single-stranded DNA is used as substrate, the Michaelis constant was about twenty -times lower than poly (U), whereas tumover numbers were similar. However, stimulation of ATPase activity was not observed in the presence of double-stranded DNA. $\mathrm{pH}$ dependent profiles of ATP hydrolysis with the helicase showed that the optimal ATPase activities were in a range of $\mathrm{pH} 6.2 \sim 6.6$. In addition, ATP hydrolysis activity assays performed in the presence of various divalent cations exhibited that $\mathrm{Mg}^{2-}$ stimulated the ATPase activity with the highest rate and $\mathrm{Mn}^{2-}$ with about $40 \%$ rate as compared to the $\mathrm{Mg}^{2+}$.
\end{abstract}

Key Wonds: Severe acute respiratory syndrome coronavirus helicase, ATP hydrolysis. Single-stranded nucleic acids. pH-Dependence profile. Divalent cations

\section{Introduction}

Helicases are molecular motor proteins that translocate on nucleic acid (NA) and separate the double-stranded (ds) NA into two single-stranded (ss) NAs using the energy generated from nucleoside triphosphate (NTP) hydroly sis. ${ }^{1.3}$ The strand separation activity of helicase is required for various processes of genome replication and recombination. It has been reported that defects in helicases lead to many human diseases including Bloom's syndrome. Werner's syndrome. and Xeroderma pigmentosum. ${ }^{4+6}$ Because of importance of helicases in biological function, a lot of studies are currently being undertaken to better understand the mechanism.

The worldwide outbreak of Severe Acute Respiratory Syndrome (SARS) was caused by a novel coronavirus ( $\mathrm{CoV}$ ) and was claimed almost 800 deaths according to World Health Organization (WHO). SARS-CoV is an enveloped and has a single-stranded RNA genome of $29.7 \mathrm{~kb} .{ }^{7,8}$ Two large polyproteins (ppla and pplab) are produced from the replicase region and these polyproteins are subsequently cleaved into individual functional polypeptides by vinıs-encoded main proteinase $\left(\mathrm{M}^{\mathrm{pro}}\right){ }^{3}$ This autoproteolysis leads to release of several non-stnictural proteins. including RNA-dependent RNA polymerase and NTPase/helicase. It has been reported that these proteins are essential for viral replication and are regarded as good targets for antiviral therapy. ${ }^{10-12}$ Recently. helicase is an emerging novel target for the development of anti-SARS agent ${ }^{13-9}$ and a lot of efforts have been made to find out inhibitors of SARS-CoV helicase and tested as drugs. ${ }^{13-16}$ RNA and DNA aptamers against SARS-CoV helicase were also reported to have inhibitory effect for nucleic acid unwinding and ATP hydrolysis activities. ${ }^{1,18}$ Previously, we

${ }^{2}$ These two anthors contributed equally to this work have purified the SARS-CoV helicase homogeneously and isolated its RNA aptamers. ${ }^{18}$ Moreover. we have shown that aryl diketoacids selectively inhibit dsDNA unwinding activity of SARS-CoV helicase and are potential inlibitors. ${ }^{16}$ In the present study. ATP lydrolysis activities of SARS-CoV helicase were measured in the presence of various types of nucleic acids using steady state kinetic analysis. The effects of $\mathrm{pH}$ conditions of reaction buffer and divalent cations on the ATPase activity were also investigated to better describe the ATP hydrolysis activity of SARS-CoV helicase.

\section{Materials and Methods}

Potein, 1eagent, and buffer: The SARS coronavinus helicase expression vector. pHelA12, was transforned into E.coli Rosetta ${ }^{\mathrm{TM}}$ competent cells. over-expressed. and purified as described previously. ${ }^{16.18}$ The protein concentration was determined by absorbance measurements at $280 \mathrm{~nm}$ in $8 \mathrm{M}$ Urea (the extinction coefficient is $67,160 \mathrm{M}^{-1} \mathrm{~cm}^{-1}$ ) and by Bio-Rad protein assay sy stem (Bio-Rad) with bovine serum albunin as a standard. Both methods provided similar concentrations. Reaction buffer $A$ was used throughout the experiments unless specified otherwise, which contained $50 \mathrm{mM} \mathrm{Tris} / \mathrm{Cl}(\mathrm{pH} 6.6)$ and $50 \mathrm{mM} \mathrm{NaCl}$.

Poly (U) and Poly $(\mathrm{C})$ were purchased from Amersham Biosciences and their concentrations were determined as described previously. ${ }^{12.210} \mathrm{M} 13 \mathrm{ss}$ DNA (M13nq18) was purified as described. ${ }^{21}$

Steady state ATPase assay. ATP lyd drolysis assay was carried out by measuring the amount of inorganic phosphate $\left(P_{i}\right)$ released from ATP. $P$, was quantified by spectrophotometric method based on the complex formation with molybdate. ${ }^{22}$ After various times of incubation. the reactions were stopped by adding color-developing solution (1 part of $10 \%$ ascorbic 
acid and 6 part of $0.42 \%$ ammonium molybdate in $1 \mathrm{~N}_{2} \mathrm{SO}_{4}$ ). The stopped reaction mixture was further incubated for $\mathrm{I} h \mathrm{~h}$ at $37^{\circ} \mathrm{C}$ and read at $820 \mathrm{~nm}$. The amount of $\mathrm{P}_{1}$ released was quantified using the $P_{i}$ standard curve. The molar concentration of $P_{i}$ was plotted versus the time of reaction, and the steady state rate was obtained from the slope of initial reaction times.

To measure the steady state ATPase rate in the presence of various NAs, $100 \mathrm{nM}$ helicase was mixed with $2 \mathrm{mM}$ ATP. 5 $\mathrm{mM} \mathrm{MgCl}$, and various concentrations of poly(U), poly(C). or single-stranded (ss) circular MI3 DNA in buffer A at $37^{\circ} \mathrm{C}$. To compare the steady state rate of ATP hydrolysis activity between ssDNA and dsDNA, $100 \mathrm{nM}$ helicase was mixed with $2 \mathrm{mM} \mathrm{ATP}, 5 \mathrm{mM} \mathrm{MgCl}$, and $3 \mathrm{nM} \mathrm{M} 13$ ssDNA or 1.2 nM pGEX-5X-1 plasmid dsDNA. Control experiment was performed same as above only in the absence of NA. The kinetic parameters $k_{r a t}$ (tumover number) and $K_{m}$ (Michaelis constant) were determined from Equation I.

$$
v^{\prime}-[E]_{0}[\mathrm{~S}] k_{c u t} /\left(K_{m} \cdot[\mathrm{S}]\right)
$$

where $v$ is the rate of the reaction, $[E]_{n}[S]$ is the maximal rate, [S] is the concentration of substrate, and $K_{m}$ is the Michaelis constant.

The effect of $\mathrm{pH}$ on ATPase activity was studied at $37^{\circ} \mathrm{C}$ in a $\mathrm{pH}$ range of 4.0 to 9.0 . Several different buffer solutions $(50$ $\mathrm{mM}$ ) of various $\mathrm{pH}$ were used as follows: sodium acetate ( $\mathrm{pH}$ $4.0 \sim 5.0$ ), MES (pH 5.5 6.2), and Tris/Cl (pH 6.5 - 9.0). 100 $\mathrm{nM}$ helicase was mixed with $2 \mathrm{mM}$ ATP, 2 nM M13 ssDNA. $5 \mathrm{mM} \mathrm{MgCl}_{2}$, and $50 \mathrm{mM} \mathrm{NaCl}$ in each different buffer condition. After various times of incubation, the reactions were quenched and the products were analyzed as above.

The dependence of A TP hydrolysis activity on the concentrations of several divalent cations was also studied at $37^{\circ} \mathrm{C}$. $100 \mathrm{nM}$ helicase was mixed with $2 \mathrm{mM}$ ATP, 2 nM MI3 ssDNA, and various concentrations of $\mathrm{MgCl}_{2}, \mathrm{MnCl}_{2}, \mathrm{CaCl}_{2}$. and $Z$ inc acetate in buffer $A$. After various times of incubation. the reactions were quenched and the products were analyzed as above.

\section{Results and Discussion}

To estimate the rate of ATP hydrolysis in the presence of poly $(\mathrm{U})$ and poly $(\mathrm{C})$ RNAs, the released $\mathrm{P}$, was quantified by formation of molybdate complex. The ATPase activity of SARS-CoV helicase was shown to be enhanced by homopolynucleotides tested. Fig. I(A) shows that the steady state ATPase rates increased in a hyperbolic mamer with increasing poly(U) concentrations providing a turnover number $\left(k_{s}\right)$ of $68.0=3.7 \mathrm{~s}^{-1}$ and a Michaelis constant $\left(K_{m}\right)$ of $11.7 \pm 2.5 \mathrm{nM}$. The effect of poly (C) concentration on the ATPase activity is shown in Fig. 1(B). The steady state rates also increased in a hyperbolic manner with increasing poly(C) concentrations providing a $k_{c t}$ of $31.1: 2.3 \mathrm{~s}^{-1}$ and a $K_{m}$ of $73.1: 18.1 \mathrm{nM}$. These results indicate that SARS-CoV helicase shows better ATPase activity in the presence of poly $(U)$ than poly $(\mathrm{C})$. When we compare the specificity constants $\left(k_{s i r} / K_{m}\right)$ of poly $(\mathrm{U})$ and poly $(\mathrm{C}), k_{c: m} / K_{m}$ value of poly $(\mathrm{U})\left(\sim 5.8 \mathrm{nM}^{-1} \cdot \mathrm{sec}^{-1}\right)$ is 15-times higher than the value of poly $(\mathrm{C})\left(-0.4 \mathrm{nM}^{-1} \cdot \mathrm{sec}^{-1}\right)$.
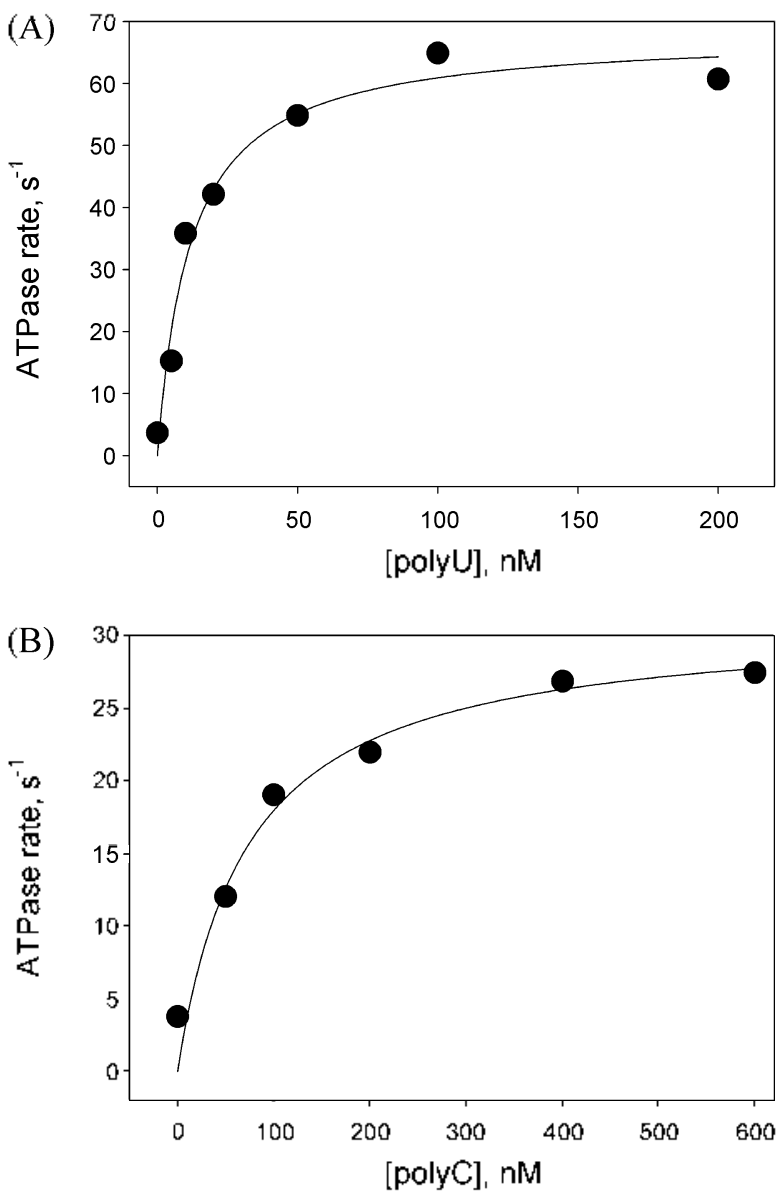

Figure 1. Measurement of ATPase activitics in the presenee of homopol nucleotide R.VAs. $100 \mathrm{nM}$ SARS-CoV helicase was mixed with $2 \mathrm{mM}$ ATP. $5 \mathrm{mM} \mathrm{MgCl}$. and various concentrat ion of poly (U) (A) and poly(C) (B) in buffer $\wedge$ at $37^{\circ} \mathrm{C}$. After various times. the reactions were quenched by adding color-developing solution and released $P_{i}$ was quantified using $P_{i}$ standard curve. The ATPase rale versus [poly(u)] tit to a liquation 1 with a $k_{c}$ of $68.0 \pm 3.7 \mathrm{~s}^{-1}$ and a $k_{n}$ of $11.7 \pm 2.5 \mathrm{nM}$. The ATPase rale versus [poly (C)] lit of a Equation I with a $k_{\text {tcat }}$ of $31.1+2.3 \mathrm{~s}^{-1}$ and $\mathrm{a} K_{i j}$ of $73.1+18.1 \mathrm{nM}$.

This is consistent with previous report describing the ATPase activity stimulation effect was most enhanced when poly(U) was used. However, it is not clear why poly(U) is better ATPase activity stimulator than other homopolynucleotide RNAs for SARS-CoV helicase.

To investigate the effect of DNA on the ATPase activity, we also carried out ATP hydrolysis analysis in the presence of M13 ssDNA. MI3 ssDNA is a 7,250 bases-long circular DNA. Since it has no end, it is expected that helicase translocates along the ssDNA continuously unless the helicase separates from the DNA. Fig. 2(A) shows that the steady state ATPase rates increased in a hyperbolic manner with increasing M13 ssDNA concentrations providing a $k_{c k+}$ of $64.9+1.0 \mathrm{~s}^{-1}$ and a $K_{m}$ of $0.63 \pm 0.04 \mathrm{nM}$. Interestingly, the steady state ATPase rate in the presence of $1.2 \mathrm{nM}$ plasnid dsDNA $\left(1.3 \mathrm{~s}^{-1}\right)$ is quite similar to the case performed in the absence of DNA $\left(0.9 \mathrm{~s}^{-1}\right)$, as shown in Fig. 2(B). Wnlike little stimulation of the ATPase activity with dsDNA, stimulation of ATPase activity by ssDNA is significant. Although $k_{\text {ezt }}$ value of MI 3 ssDNA is similar to 
that of poly(U), $K_{1}$ ? value for ATP hydrolysis stimulation is much lower than that of poly(U) and poly(C). It appears that binding of SARS-CoV helicase to ssDNA is tighter than SsRNA. Other explanation would be the helicase exhibit similar preferences for nucleic acids regardless of DNA or RNA, because smaller $K_{12}$, value for ATP hydrolysis with the M13 ss[DNA can be explained by more amounts of nucleotides $(\cdots 7,000 \mathrm{nts})$ in one molecule than that of RNA homopolymer ( $100 \cdots 300$ nts per molecule) used in this study.

In the absence of DNA. ATP hydrolysis was negligible and about 70-times slower than the ATPase rate observed in the presence of MI3 ssDNA. It is very common to almost all of helicases that nucleic acid binding stimulates the NTPase activity of helicases. Since biological role of helicase by itself is translocation along ssNA and dsNA unwinding, chemical
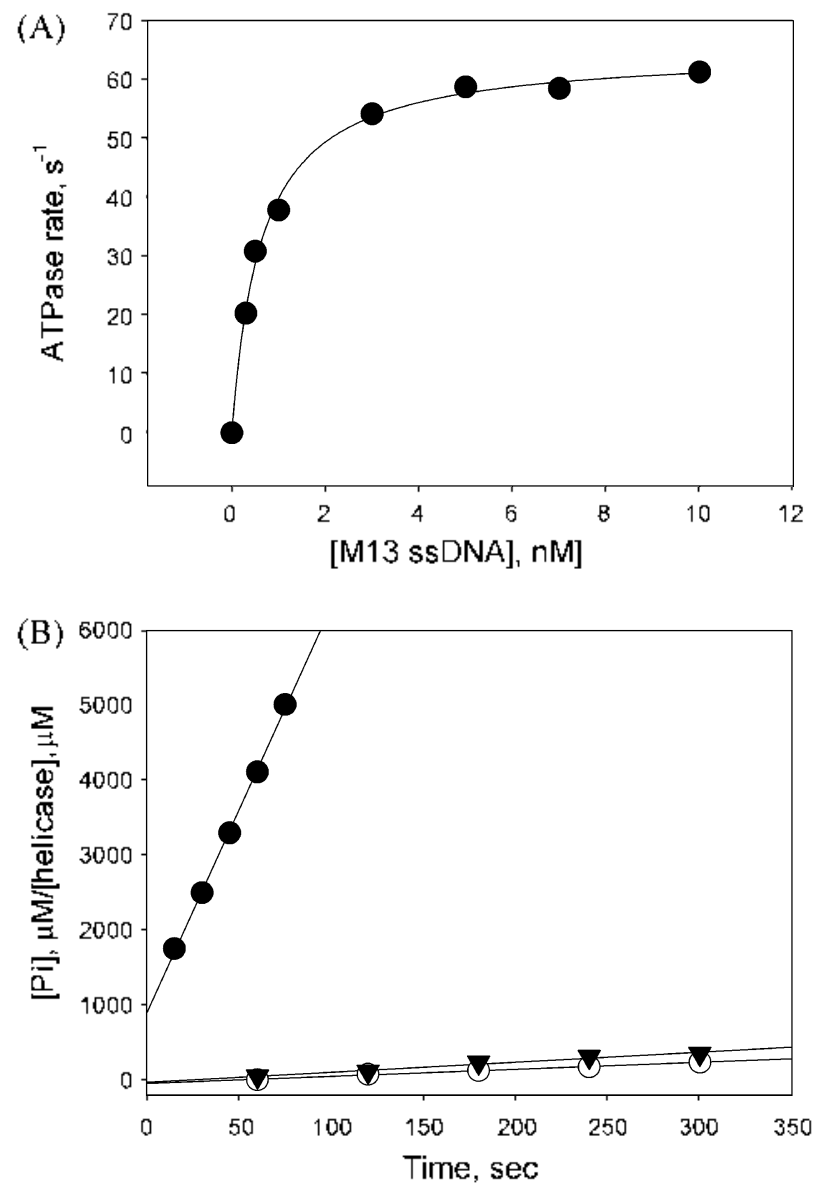

Figune 2. (A) 100 t1M SARS-CoV helicase was mixed with $2 \mathrm{mM}$ ATP. $5 \mathrm{mM} \mathrm{MoCl}$. and various concentration of $\mathrm{M} 13$ ssDNA in buller $A$ at $37^{\circ} \mathrm{C}$. Alter various times, the reactions were quenched by adding color-developing solution and released $P_{i}$ was quantilied

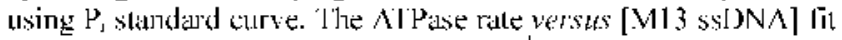
to a Equation 1 with a $k_{\text {sur }}$ of $64.9+1.0 \mathrm{~s}^{-1}$ and a $K_{m}$ of $0.63+0.04$ n.M. (B) 3 nM M13 ssDNA (•). I.2 n. p (GEX-5X-I plasmid dsDNA (v). or no IJNA (O) was mixed with $100 \mathrm{nM}$ SARS-CoV helicase. $2 \mathrm{mM}$ AIP. $5 \mathrm{mM} \mathrm{MgCl}$ in bulfer $A$ an $37^{\circ} \mathrm{C}$. Alier various times. the reactions were quenched by addine color-developing solution and released $P_{i}$ was quantified using $P_{i}$ standard curve. Stcady stale Al'Pase rate was oblained from the slope. ATPase rates were

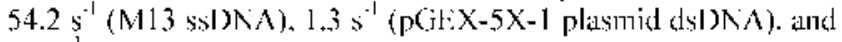
$0.9 \mathrm{~s}^{-1}$ (no DNA). respectively. energy generated fiom NTP hydrolysis is necessary for efficient movement. It has been reported that DNA or RNA stimulates NTP hydrolysis 10 - to 100 - fold ${ }^{2-2-2 f_{1}}$ Interestingly, SARS-CoV helicase does not stimulate ATP hydrolysis activity in the presence of dsDNA, indicating that SARS-CoV helicase does bind only ssNA but not dsNA. Previous dsDNA unwinding experiment with fully dsDNA (blunt ended) did not show dsDNA unwinding activity, which supports our current results. ${ }^{2 \hat{3}}$ In general, the binding of ssNA stimulates the NTPase activity of helicases. which is believed that ssNA induces protein conformational change and allow the NTP hydrolysis to proceed. ${ }^{27}$ Comparison of the kinetic parameters in the presence of poly(U) and $\mathrm{MI} 3$ ssDNA suggests that SARS-CoV helicase does not show strict selectivity for ssNA, although $k_{\text {cut }}$ value of poly(C) is lower than other ssNA. In contrast to SARS-CoV helicase classified as superfamily 1 , hepatitis $\mathrm{C}$ virus (HCV) helicase, other RNA helicase that belongs to superfamily 2 , binds a DNA substrate 40-times faster than RNA and shows better DNA unwinding activity than $\mathrm{RNA}^{28}$ Based on these results, ATPase activity experiments with SARS-CoV helicase were performed with M13 ssDNA hereafter.

The $\mathrm{pH}$ dependence of ATPase activity in the presence of M13 ssDNA shows that the optimal $\mathrm{pH}$ condition exists within the range of 6.2 to 6.6 (Fig. 3). On the contrary, steady state rates of ATPase activity below 6.0 and above 7.0 decreased less than $70 \%$ of maximum value. Previous studies have shown that nucleotide hydrolysis activity of helicase is greatly enhanced by binding to ssNA. Therefore, the factors that influence on the binding to NA, such as pH or metal ions, could be responsible for ATPase activity of SARS-CoV helicase. It is well known that the activities of enzymes are dependent on $\mathrm{pH}$ in the same way of acid-base ionization. In fact, many helicases show their optimum nucleotide hydrolysis activities at different $\mathrm{pH}$ conditions (for example, T7 bacteriophage helicase: $\mathrm{pH}$ $7.6{ }^{29}$ Hepatitis $\mathrm{C}$ virus NS3h helicase: $\mathrm{pH} 7.0{ }^{30}$ E.coli DnaB helicase; $\mathrm{pH} 8.1^{31} \mathrm{etc}$ ). In the case of SARS-CoV helicase, the optimal pH for ATP hydrolysis is a little lower than other helicases.

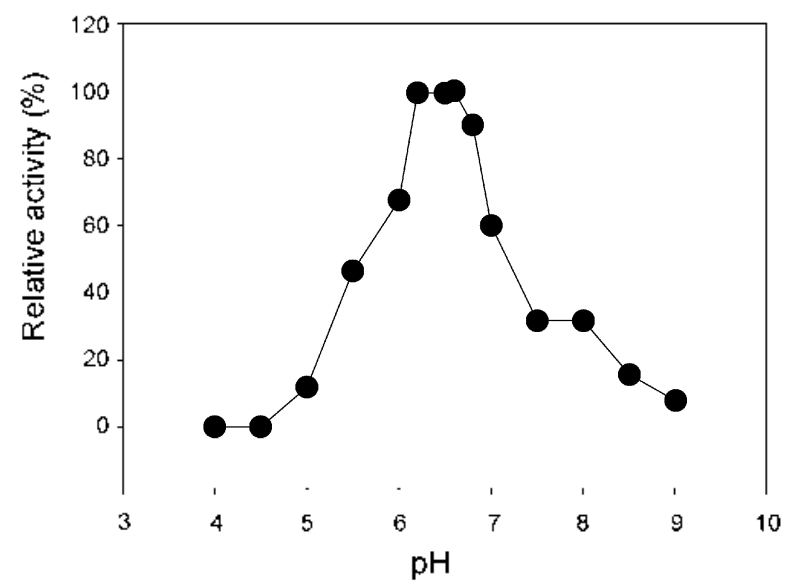

Figure 3. $\mathrm{pH}$ dependence protile of ATPase activity: ATPase rates were measurud with $100 \mathrm{nM}$ SARS-CoV helicase. 2 mM ATP. $5 \mathrm{mM}$ $\mathrm{MgCl}=2 \mathrm{nM} \mathrm{MI} 3 \mathrm{ssl}) \mathrm{NA}$, and $50 \mathrm{mM} \mathrm{NaCl}$ in several bufler solutions at $37^{\circ} \mathrm{C}$ and al various pll The ATP ase activity was normalized to the maximal activity. 


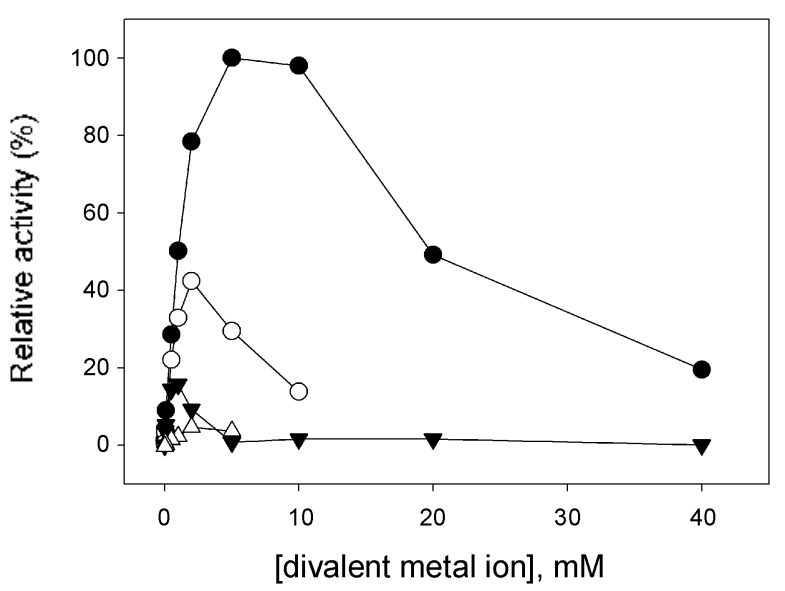

ligure 4. Iependence of ATPase rate on the concentration of various divalent metal ions. $100 \mathrm{nM}$ helicase was mixed with $2 \mathrm{~m} . \mathrm{M} \mathrm{ATP}$. $2 \mathrm{n.M}$.M13 $\mathrm{ssDNA}$. and various concentrations of $\mathrm{MgCl}_{2}(\bullet) . \mathrm{MnCl}_{2}$ (o). $\mathrm{CaCl}_{2}\left(\right.$. .) and \%inc acelate $(\nabla)$ in butler $\mathrm{A}$ at $37^{\circ} \mathrm{C}$. The AT ase activily was normalized to the maximal activity obtained with $\mathrm{MgCI}_{2}$.

In general, optimal $\mathrm{pH}$ conditions for dsNA unwinding and NTPase activity are similar unless salt concentrations change. Thus, it is expected that optimal pH conditions for dsNA unwinding would be similar to ATPase activity. Our results provide the basic experimental information for further studies of ATP hydrolysis and nucleic acid unwinding by SARS-CoV helicase.

Since there have been many reports regarding the stimulated NTPase activity by RNA virus helicases with divalent cations, the stimulatory effects of divalent metal ions on ATP hydrolysis by SARS-CoV helicase were investigated using four different kinds of metal ions. Steady state ATP hydrolysis experiments were carried out in the presence of $\mathrm{Mg}^{2+}, \mathrm{Mn}^{2+}$, $\mathrm{Ca}^{21}$, and $\mathrm{Zn}^{21}$. Fig. 4 shows the effect of divalent inetal ion concentrations on the ATPase activity. Among the divalent cations tested, $\mathrm{Mg}^{2+}$ shows the optimal stimulation of ATPase activity. ATPase activity increases up to $5 \mathrm{mM}$ of $\mathrm{Mg}^{2}$, and decrease thereafter. $\mathrm{Mn}^{2-}$ could be a substitute for $\mathrm{Mg}^{2+}$, but the highest ATPase activity at $2 \mathrm{mM} \mathrm{Mn}^{21}$ is only about $40 \%$ of $\mathrm{Mg}^{2+}$ at $5 \mathrm{mM}$. In the case of $\mathrm{Ca}^{2+}$ or $7.1^{2-}$, the maximum ATPase activity was less than $20 \%$ of $\mathrm{Mg}^{2+}$. Recent computerbased three dimensional model of SARS-CoV helicase showed that it has six conserved motifs that are characteristic for superfamily 1 helicases, and motif $\mathrm{I}$ and II. specifically Lys 288 residue in motif $l$ by contacting the $\beta$-phosphate of the bound NTP. play an important role when NTP- $\mathrm{Mg}^{2 \cdot}$ complex binds the helicase and proceed to hydrolyze. ${ }^{32} \ln$ addition, the complex ATP with SARS-CoV helicase closely resembles the crystal structure of PcrA helicase, another member of superfamily 1 helicases, which suggests that SARS-CoV helicase may follow similar divalent cation dependent ATP hydrolysis pattern of other superfamily 1 helicases. In previous studies of $\mathrm{PcrA}^{33}$. $\mathrm{Mg}^{2-}$ binding can stabilize ATP- $\mathrm{Mg}^{2-}$ complex in the correct conformation to hydrolyze ATP. Likewise in the computer-based model of SARS-CoVhelicase, L ys 37 residue of PcrA is positioned at the $\mathrm{Mg}^{2}$ binding site and is important for ATP hydrolysis through conformational change.
Here we report the studies of ATP hydrolysis activities by SARS-CoV helicase in the presence of various NAs, divalent cations, and at different $\mathrm{pH}$. We demonstrate that ATPase activity is stimulated by ssNA and $k_{c u} / K_{m p}$ value is the highest in the presence of MI3 ssDNA. ATP hydrolysis by the helicase is also influenced by $\mathrm{pH}$ conditions of reaction. As other superfamily I helicase, $\mathrm{Mg}^{2}$ shows the optimal metal ion cofactor for ATP hydrolysis. Taken together, we provide basic analysis of ATPase activity and optimal ATPase reaction condition for further studies to develop the helicase-target antiviral inhibitors.

Acknowledgments. This work was supported by the Korea Research Foundation Grant funded by the Korean Government (MOEHRD) (KRF-2006-3 I2-C00594) and Seoul R\&BD program ( 10580 ) endowed to $\mathrm{Y}-\mathrm{J}$. $\mathrm{J}$. and by a grant $(2008040$ 1034026) from the BioGreen 2I Program, Rural Development Administration, Republic of Korea, endowed to [D-E. K.

\section{References}

I. Patel. S. S.; Picha. K. M. Ammt. Rev. Biochem 2000. 69. $65 \mathrm{I}$.

2. Patel S. S.: Donme\% I. / Biol Chem. 2006. 281. 18265.

3. Lohman. T. M.; Bjornson. K. P. Amm. Rev. Biochem. 1996. 65. 169.

4. I:Ilis. V. A.; Groden. I,; Ye. I, \%,; Straughen, J.: I ennon. I), I,; Ciocei. S.. Proyteheva. M.: (jerman. J. Ce// 1995. 83.655.

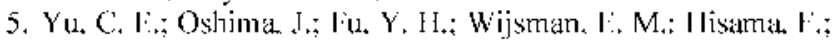
Alisch. R.; Matthews. S.; Nakura. J.; Miki. T.; Ouais. S.; Martin. G. M.; Mulligan. J.: Schellentere. G. D. Science 1996. 272. 258.

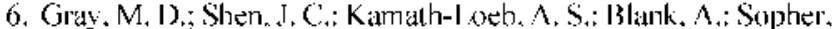
B. L.: Martin. G. M.: Oshima. J.: Locb. L. A. Nature Genet. 1997. 17.100

7. Marra. M. A.: Jones. S. J.: Astell. C. R.; Holt. R. A.: BrooksWilson. A.; Buttertield. Y. S.; Khattra. J.; Asano. J. K.: Barber. S. A.: Chan. S. Y.: Cloutier A. Coughlin. S. M.: Freman, D); Girn. N.: Griffith. O. L.: Leach. S. R.: Mavo. M.: MeDonald. H.: Monlgomery, S. 13.: Pandol, P. K.: Pelrescu. A. S.: Robertson. A. G.; Schein. J. E.: Siddiqui. A.; Smailus. D. E.; Stott. I. M.; Yang. G. S.; Plummer. F.; Andonov. A.: Artsob. H.; Basticn. N.:

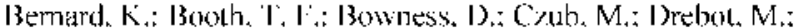
Furnando. L.: Flick. R.; Garbutt. M.; Gray. M.; Grolla. A.: Jones. S.: leldmann. Il.: Meyers. A.: Kabani. A.: I.i. Y.: Normand, S.: Stroher, U.: Tipples, G. A.: lyler. S.: Vogrig. R.: Ward. D.: Watson. B.: Brunham. R. C.: Krajden. M.: Petric. M.: Skow ronski. D. M.: Upton. C.: Roper, R. I. Science 2003. 300.1399.

8. Rota P. A.: Ohorste. M. S.; Monrox. S. S.: Nix. W. A.: Campaenoli. R.: Icenogle. J. P.: Penaranda. S.: Bankiamp. B,: Malher, K.:

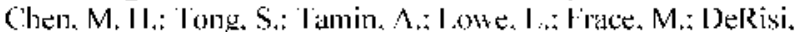
J. L.: Chen. Q.: Wang. D.; Erdman. D. D.; Peret. T. C.: Burns. C.; Kiazet. 'T, G.: Rollin, P. I., Sanche\% $\Lambda$, I iflick, S.: I lolloway. B.; Limor. I.: McCaustland. K.: Olsen-Rasmussen. M.; Fouchier. R.: (junther. S.: Osterhaus, A. I), I Drosten . C.: Pallansch. M. A.: Anderson. I., J.: Bellini. W. I. Science 2003. 300.1394.

9. Zisbuhr. J. (uwt. Opin. Wicrobiol 2004. 7. 412.

10. Ilolmes, K. V. J. Clin. hovest. 2003. //1. 1605

II. Anand. K.; Zisbuhr. J.: Wadhwani. P.; Mosters. J. R.; Hilgenfeld. R. Science 2003, 300. 1763 .

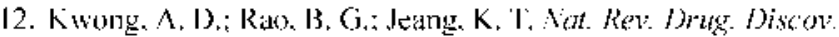
2005. +.845 .

13. Yang. N.: Tanner, J. A.; Wang, /.; H luang, J. D.: Zheng. I3. I.: Zhu. N.: Sun. H. Chent Commuth f( $\mathrm{camb})$ 2007. 42.4413.

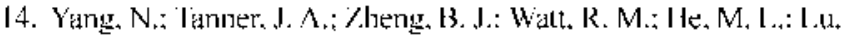
I.. Y.: Jiang. J. Q.: Shum, K. I.: I in, Y. P.: Wong. K. I..: I in . M. C.: Kung. H. F.: Sun. H.: Huang. J. D. Angew. Chem. Im. Ed. 
Engl. 2007, 46, 6464.

15. Tamner, J. A.; Zheng, B. T.; Zhou, J.: Watt, R. M.: Tiang, T. Q.: Wong, K. L.; Lin, Y. P; Lu, L. Y.; He, M. L.; Kung, H. F.; Kesel, A. T. Huang, J. D. Chem. Biol. 2005, 12, 303.

16. Lee, C.: Lee, J. M.: Lee, N. R. Tin, B. S.: Jang, K. I.: Kim, D. E.: Teong, Y. J.: Chong, Y. Bioorg. Med Chem. Lett. 2009, 19, 1636.

17. Shum, K. T: Tanner, J. A. Chembiochem. 2008, 9, 3037.

18. Tang, K. J.; Lee, N. R; Yeo, W. S: Teong, Y. J; Kim, D. E. Biochem. Biophvs. Res. Commm 2008, 366, 738.

19. Levin, M. K.: Patel, S. S. J. Biol. Chem. 2002, 277, 29377.

20. Teong, Y. J.: Kin, D. E.: Patel, S. S. J. Biol Chem. 2004, 279, 18370 .

21. Sambrook, T.; Fritsch, E. F.; Maniatis, T. In H lolecular Cloning, A Laboratony Hamal, Second ed; Ford, N,; Nolan, C.; Ferguson, M., Eds.: Cold Spring Harbor Laboratorty Press: 1989.

22. Piper, T. M.: Lovell, S. J. Antal Biochem. 1981, 117, 70.

23. Tanner, J. A; Watt, R. M.; Chai, Y. B.; Lu, L. Y.; Lin, M. C.; Peiris, I. S.: Poon, L. L.: Kung, H. F.: Huang, J. D. J. Biol. Chem. 2003, 278, 39578
24. Washington, M. T.; Rosenberg. A. H.: Griffin, K.: Studier, F. W.; Patel, S. S. J. Biol. Chem. 1996, 271, 26825.

25. Patel, S. S.; Rosenberg, A. H.: Studier, F. W.: Johnson, K. A.J. Biol. Chent 1992, 267, 15013.

26. Matson, S. W.; Richardson, C. C. J. Biol. Chem. 1983, 258 , 14009 .

27. Kadare G.: Haenni, A. L. J. Firol. 1997. 71.2583.

28. Pang, P. S.; Jankowsky, E.; Planet, P. T.; Pyle, A. M. El IBO J. $2002,21,1168$.

29. Jeong, Y. J.: Kim, D. E.; Patel, S. S. J. Biol. Chem. 2002, 277 , 43778 .

30. Levin, M. K.; Patel, S. S. J. Biol. Chem. 1999, 27 31839.

31. Rajendran, S.; Jezewska, M. T.; Bujalowski, W. J. Mol. Biol. $2000,303,773$

32. Hoffmann, M.: Eitner, K.: von Grotthuss, M.; Rychlewski. L: Banachowicz. E.: Grabarkiewicz. T.; Szkoda, T.; Kolinski, A. $J$. Contput Aided i fol Des. 2006, 20, 305.

33. Soultanas, P.; Dillingham, M. S.; Velankar, S. S.; Wigley, D. B. J. hol. Biol 1999, 290, 137. 